\title{
Correction to: Evaluation of admission levels of $P, E$ and $L$ selectins as predictors for thrombosis in hospitalized COVID-19 patients
}

\author{
Mona M. Watany ${ }^{1}\left[\right.$ D $\cdot$ Said Abdou ${ }^{1} \cdot$ Reham Elkolaly $^{2} \cdot$ Nashwa Elgharbawy $^{3} \cdot$ Hossam Hodeib $^{1}$
}

Published online: 16 February 2022

(c) The Author(s) 2022

\section{Correction to: Clinical and Experimental Medicine https://doi.org/10.1007/s10238-021-00787-9}

The original version of this article unfortunately contained a mistake. Author name Said Abdou was incorrectly written as Saied Abdou.

Open Access This article is licensed under a Creative Commons Attribution 4.0 International License, which permits use, sharing, adaptation, distribution and reproduction in any medium or format, as long as you give appropriate credit to the original author(s) and the source, provide a link to the Creative Commons licence, and indicate if changes were made. The images or other third party material in this article are included in the article's Creative Commons licence, unless indicated otherwise in a credit line to the material. If material is not included in the article's Creative Commons licence and your intended use is not permitted by statutory regulation or exceeds the permitted use, you will need to obtain permission directly from the copyright holder. To view a copy of this licence, visit http://creativecommons.org/licenses/by/4.0/.

Publisher's Note Springer Nature remains neutral with regard to jurisdictional claims in published maps and institutional affiliations.

The original article can be found online at https://doi.org/10.1007/ s10238-021-00787-9.

Mona M. Watany

mona.watany@med.tanta.edu.eg

1 Clinical Pathology Department, Faculty of Medicine, Tanta University, Medical Campus, El Giesh st., Tanta, El-Gharbia Governorate, Tanta 31527, Egypt

2 Chest department, Faculty of Medicine, Tanta University, Tanta, Egypt

3 Internal Medicine Department, Faculty of Medicine, Tanta University, Tanta, Egypt 